\title{
Field assessment of the microclimatology of tropical flank margin caves
}

\author{
Douglas W. Gamble*, Joseph T. Dogwiler, John Mylroie \\ Department of Geosciences, Mississippi State University, PO Drawer 5448, Mississippi State, Mississippi 39762, USA
}

\begin{abstract}
Temperature observations were collected inside 2 caves in the Bahamas and 1 cave in Puerto Rico to characterize the microclimatology of tropical flank margin cave systems. Three aspects of these tropical cave temperatures agree with temperate cave microclimate theory. Specifically, external atmospheric disturbances can affect temperatures inside tropical flank margin cave systems, tropical flank margin caves are warmer than the exterior temperatures during winter, and water can impact temperatures deep into a tropical flank margin cave system. The temperature observations collected also indicate potential differences between the microclimatology of tropical and temperate cave systems. In particular, the temperate 3-zone cave microclimate model may not be applicable to tropical flank margin caves, diurnal fluctuations were not apparent in tropical flank margin cave systems, and the existence of a temperature inversion in a down-sloping cave may not be applicable to all tropical flank margin caves. The potential differences in temperate and these tropical cave systems can be linked to the physical dimensions of the tropical flank margin cave systems and the unique hydrology of small carbonate islands. Specifically, tropical flank margin caves have a width greater than length while temperate fluvio-karst caves have a length greater than width and tidal water can exist in the pits and depressions of tropical flank margin caves as opposed to flowing streams in temperate cave systems.
\end{abstract}

KEY WORDS: Microclimatology · Tropical caves · Bahamas · Puerto Rico · Cave climate

\section{INTRODUCTION}

The microclimatology of caves has received considerable attention due to its impact upon cave morphology, biology, paleontology, and management. For example, Dublyansky \& Dublyansky (1998) reviewed cave microclimate processes and related how they may result in condensation-corrosion and dissolution in caves; de Freitas \& Littlejohn (1987) investigated the impact of cave microclimate upon sensitive cave fauna and cave management; Poulson \& White (1969) outlined the climate of caves and its influence upon cave organisms; and Trapesso \& Kaletsky (1994) measured

\footnotetext{
*Present address: Department of Earth Sciences, University of North Carolina at Wilmington, 601 S College St, Wilmington, North Carolina 28405, USA. E-mail: gambled@uncwil.edu
}

the impact of Snowball Dining Room upon the microclimate of Mammoth Cave. Despite the initial belief that cave microclimate is constant and static, much research has documented the variability of microclimatic parameters, and a 3-zone model has been developed to describe the general zones of climatic variability within a cave (Cropley 1965, Poulson \& White 1969). According to this 3-zone model, a twilight zone exists near the cave entrance with greatest variability in microclimate parameters. Moving from the entrance towards the interior of the cave, the influence of exterior climatic conditions diminishes and a middle zone exists in complete darkness with some variability in cave microclimate. Further in the cave, at the rear, a deep cave zone exists with constant microclimatic conditions.

One limitation of the application of this 3-zone model and other principles of cave microclimatology is that 
they have been developed almost exclusively from observations in mid-latitude/temperate regions. For instance, in Wefer's (1991) annotated bibliography of cave microclimatology, the most extensive listing of literature pertaining to the subject, only 3 out of 221 sources listed pertain to tropical cave systems. Thus, researchers investigating tropical cave microclimatology are challenged by the absence of an appropriate cave microclimate theory and models. Tarhule-Lips \& Ford (1998) found the 'turbulent pipe flow' model (Wigley \& Brown 1976) requires considerable modification in order to be applicable to caves in Puerto Rico and the Cayman Islands.

The purpose of this study is to collect temperature observations from tropical flank margin cave systems and compare the observations to existing temperate cave climate theory. The comparison will allow the initial characterization of the similarities and differences between tropical and temperate cave climatology.

Several factors exist which may cause differences in tropical and temperate cave climatology. These differences can be separated into 2 broad categories, exterior conditions and formative processes/physical dimensions. In regard to exterior conditions, the tropics experience a higher annual temperature with minimal seasonal variation. Thus, as compared to temperate caves, tropical caves may be expected to be warmer and less variable.

The formative processes/physical dimensions of a cave control the interface with the exterior climate and the circulation of air through the cave system (Wigley \& Brown 1976, de Freitas et al. 1982). On small carbonate islands, flank margin caves are dominant, while fluvio-karst caves dominate continental temperate regions. These 2 types of caves have drastically different physical characteristics. Flank margin caves form in the distal margin of a freshwater lens, under the flank of the island, where freshwater and seawater mix and produce dissolutionally aggressive water (Mylroie \& Carew 1990, Mylroie et al. 1995). Flank margin caves tend to have globular chambers interconnected in a 'beads on a string' pattern. Entrances to flank margin caves are strictly collapse features not necessarily related to speleogenesis. Fluvio-karst caves are formed by the drainage of water through a limestone aquifer (Ritter et al. 1995). Conduits arranged in an organized drainage pattern characterize fluvio-karst caves. Thus, entrances may be cogenetic with the formation of the cave. Flank margin caves typically have a width greater than the length; fluvio-karst caves have a length greater than the width. Flowing streams are typically absent in flank margin caves and present in fluvio-karst caves.

This study does not discuss a third, intermediate category, that of fluvio-karst caves developed in tropical settings. Tropical continental settings, and larger tropical islands that contain both carbonates and non-carbonate rocks, develop classic fluvio-karst caves similar to the well-described fluvio-karst caves in temperate continental settings. Flank-margin caves are unique to tropical islands, and on small tropical islands may be the only significant cave that has developed. Use of tropical flank margin caves in this preliminary study provides a database from a distinct end-member condition of cave development in the tropics.

\section{METHODOLOGY AND STUDY AREA}

Onset Hobo H8 Temperature Sensors ${ }^{\mathrm{TM}}$ were placed in 3 caves in horizontal and vertical transects and programmed to collect temperature observations ranging from every 1.5 to every $20 \mathrm{~min}$. The Hobo H8 sensor records temperature observations between -20 and $70^{\circ} \mathrm{C}$ with an accuracy of $\pm 0.7^{\circ} \mathrm{C}$ and a resolution of $0.4^{\circ} \mathrm{C}$. In addition, where possible, 1 data logger was placed outside each cave entrance to observe external air temperatures during the data collection period.

At the end of each data collection period, observations were downloaded from the temperature sensors to a laptop computer, and these observations were imported into software for graphical and statistical analysis. Graphs of moving averages of temperature observations over the period of study were created and basic descriptive statistics (mean, range, coefficient of variation) were calculated along with linear regression models of the relationship between cave temperature and exterior temperatures. The graphs, basic descriptive statistics, and linear regression models were then used to compare magnitude and variability of temperatures and the relationship between cave and external conditions. The moving averages are used in graphical analysis to assess general trends in the data, diminishing the visual impact of variance in the data.

Sling psychrometers were used to measure cave air temperatures near temperature sensors when researchers placed the sensors in and retrieved the sensors from the caves. The purpose of the sling psychrometer measurements was to calibrate the temperature observations recorded by the Hobo H8 temperature sensors. The Hobo H8 sensors offer an approximate measure of air temperature since they are housed in a waterproof casing. The sling psychrometer records air temperature without the interference of the waterproof casing and offers a more reliable measurement of cave air temperature.

In the case of the Bahamian caves, the Hobo H8 sensors recorded temperature observations lower than the sling psychrometer. The range of the sling psychrometer measurements in Garden Cave was 22.0 to $26.0^{\circ} \mathrm{C}$, 
while the Hobo H8 sensors recorded temperatures with a range of 19.4 to $24.8^{\circ} \mathrm{C}$. In Crescent Top Cave, the range of sling psychrometer measurements was 25.5 to $28.0^{\circ} \mathrm{C}$, and the Hobo $\mathrm{H} 8$ sensors recorded temperatures in the range of 24.4 to $27.6^{\circ} \mathrm{C}$. The range of the Hobo $\mathrm{H} 8$ sensors was higher than the range of sling psychrometer measurements in Cueva de los Pajarros. The range of sling psychrometer measurements in Cueva de los Pajarros was 25.5 to $28.0^{\circ} \mathrm{C}$, and Hobo $\mathrm{H} 8$ sensors recorded temperatures ranging from 26.3 to $30.7^{\circ} \mathrm{C}$. The high temperatures recorded by the Hobo H8 sensors are more than likely the result of insolation heating the waterproof casings. The sensors deep in Cueva de los Pajarros that did not have sunlight striking the surface of the waterproof casing recorded temperatures ranging between 26.3 and $26.7^{\circ} \mathrm{C}$, well within the range of the sling psychrometer measurements. Thus, the temperature observations from the Hobo H8 sensors may not represent a true measurement of the actual cave air temperature. However, the observations collected by the Hobo H8 sensors do represent a close approximation of cave air temperature, and most important of all, a relative measurement allowing for the description of temperature patterns throughout tropical flank margin cave systems.

Three different caves were chosen to be included in this study in order to characterize the thermal microclimate for a range of physical structures common to tropical flank margin cave systems. The first cave, Garden Cave, San Salvador Island, Bahamas, is a small, young (<125 Ka; Carew \& Mylroie 1995) flank margin cave with a single, wide entrance and no standing water present. The second cave, Crescent Top Cave, San Salvador Island, Bahamas, is a small, young (<125 Ka; Carew \& Mylroie 1995) flank margin cave with a small entrance and standing water present in a pit at the back of the cave. Cueva de los Pajaros, Isla de Mona, Puerto Rico, represents a large, old (>1.67 Ma; Panuska et al. 1998) flank margin cave with multiple large entrances and no standing water present in the cave.

The physical structure (size, passage configuration, and number of entrances) of a cave has been identified as one of the most important controls on cave microclimatology (Bogli 1980, de Freitas et al. 1982). In particular, it has been noted that the number of entrances to a cave is one of the greatest contributors to variability in the microclimate of a given cave. The entrances to a cave represent the interface at which the external atmosphere interacts with the interior cave microclimate through air movement (Bogli 1980). At the entrance of a cave, air movement allows for the transfer of external atmospheric conditions into the cave. Thus, the greater the number of entrances the greater the number of interfaces for air movement and transfer of external atmospheric characteristics to the interior of the cave. Based on the number of entrances, caves can be separated into static and dynamic caves (Niven \& Hood 1978). Static (or sack caves) caves only have 1 entrance and limited interaction with the external atmosphere. Dynamic (or transit) caves have multiple entrances and have a greater interaction with the external atmosphere.

The causes of air movement across cave entrances can be related to the external environment and the physical features of the cave (Bogli 1980, Smithson 1993). The most common cause of the exchange of air is the difference in air density that is created by the temperature difference between exterior and interior air temperatures. Cool air inside a cave has a lower density than warmer exterior air and will flow along the floor from the rear of the cave towards the entrance. In a single-entrance, down-sloping cave, cold external air can drain into the cave in winter and produce a slow wind at floor level. Multiple entrance caves can develop chimney-effect winds through temperature differences outside cave entrances. Rare causes of air movement across entrances can be attributed to entrainment of air by flowing water, resonance of air in large chambers, or changes in the volume of air in a cave when it is flooded. Thus, to develop an accurate characterization of caves in a tropical location, caves with different physical structure and a different number of entrances should be used to observe the different microclimates that exist in tropical flank margin caves. This study cannot directly address the specific impact of specific physical structures or single versus multiple entrances on tropical flank margin cave microclimate. However, it can offer a general characterization of the thermal environment for caves with different physical structures and identify potential differences or similarities.

The first 2 caves included in the analysis are on San Salvador Island, Bahamas. San Salvador Island is $640 \mathrm{~km}$ east-southeast of Miami, Florida, and is $11.2 \mathrm{~km}$ long and $7 \mathrm{~km}$ wide (Shaklee 1994). San Salvador represents one of the small isolated carbonate platforms common to the southeastern Bahamas (Carew \& Mylroie 1997). Due to the carbonate nature of the rock, caves and subterranean voids are common throughout the Bahamas and San Salvador Island. Four general types of caves exist: pit caves, flank margin, banana holes, and lake drains (Mylroie et al. 1995). The 2 caves on San Salvador Island included in this study are flank margin caves. Both caves are located at interior locations next to saline ponds in the north-northeast portion of San Salvador (Fig. 1).

The main chamber of the first cave, Garden Cave, is oriented northwest-southeast, with a single entrance facing southeast and the back of the cave to the north- 
west. The chamber length is $15 \mathrm{~m}$ along the northwestsoutheast axis, and the width is $5 \mathrm{~m}$ along the southwest-northeast axis, (Fig. 2). The entrance is reached by dropping down into a $1.5 \mathrm{~m}$ deep banana hole. Inside the cave itself, the floor is level from entrance to back (no slope to cave floor) and the height from ceiling to floor ranges from $1.5 \mathrm{~m}$ near the entrance to $2 \mathrm{~m}$ in the back of the cave.

Temperature sensors collected temperature observations in Garden Cave every $1.5 \mathrm{~min}$ from 11:30 h December 29 to 09:00 h December 31, 1997. The horizontal transect consisted of temperature sensors placed approximately every $4 \mathrm{~m}$ from the entrance of the cave to the rear, and the vertical transect was constructed by attaching temperature sensors approxi-

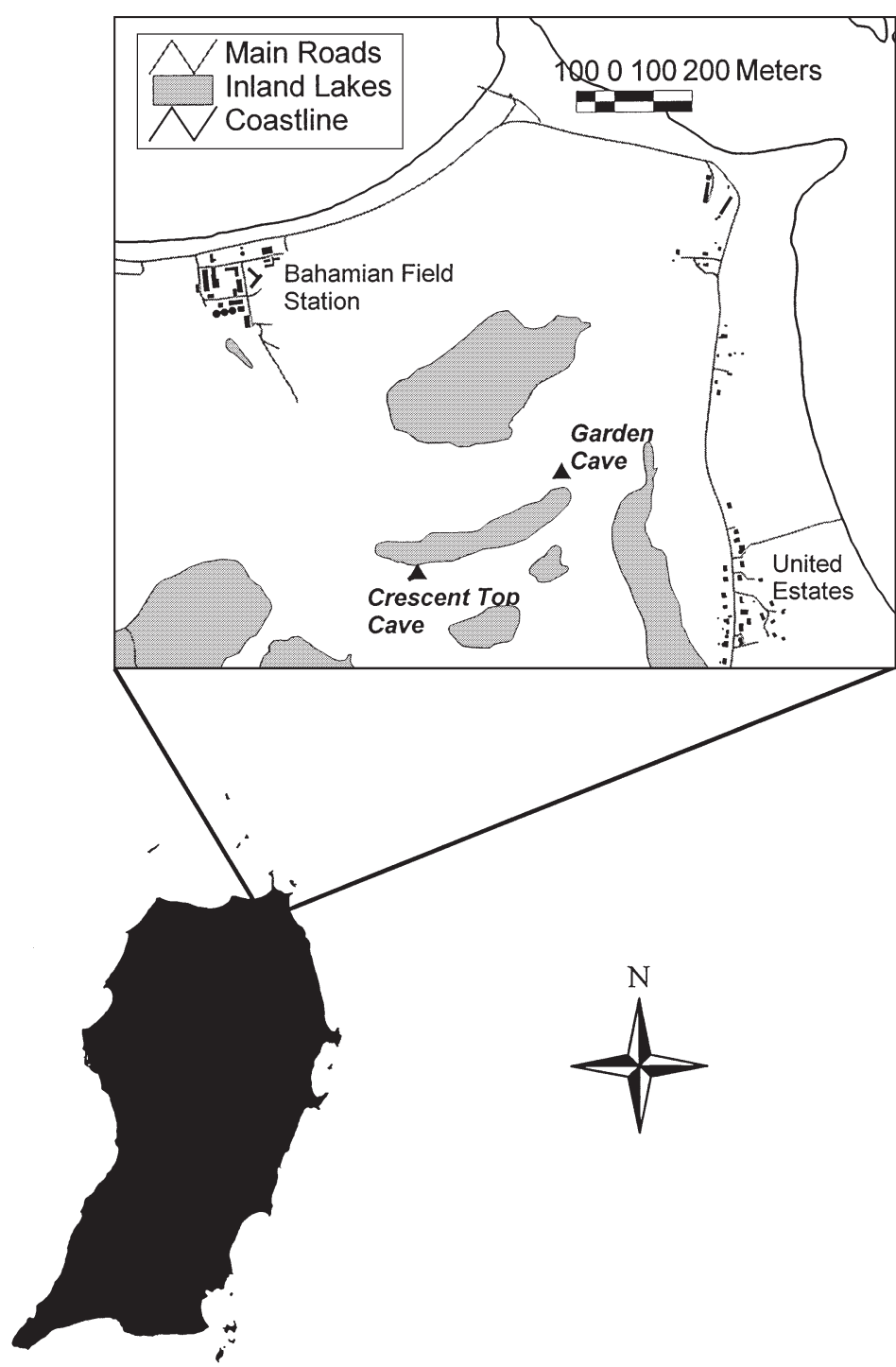

Fig. 1. Location of Crescent Top Cave and Garden Cave on San Salvador Island, Bahamas mately every $0.5 \mathrm{~m}$ on a suspended rope at the rear of the cave. Both the horizontal and vertical transects were in the main chamber of Garden Cave.

The second cave, Crescent Top Cave, is oriented north-south, with a single entrance facing north-northeast (Fig. 3). The cave can be divided into 2 parts: a main chamber and 2 sub-chambers. The main chamber, where temperature observations were recorded, is $15 \mathrm{~m}$ along the north-south axis and $6 \mathrm{~m}$ wide on the west-east axis. Within $3 \mathrm{~m}$ of the entrance of the cave and the main chamber, cave floor slopes downward toward the interior of the cave to a depth of approximately $1 \mathrm{~m}$ below the cave entrance. After this initial downward slope, the cave floor remains level. The distance from the floor of the main chamber to the ceiling is $1.5 \mathrm{~m}$, except for the back of the cave, where a pool of water exists in a pit, and the distance from the floor of the pool to the ceiling of the cave is $6 \mathrm{~m}$. The 2 sub-chambers of the cave represent an area that is $8 \mathrm{~m}$ along the north-south axis and $15 \mathrm{~m}$ along the westeast axis. The height of these chambers ranges from 0.5 to $1.5 \mathrm{~m}$. Instruments were only placed in the main chamber of Crescent Top Cave due to the limited number of available temperature sensors.

In Crescent Top Cave, temperature sensors collected temperature observations every 5 min from 15:00 h January 1 through 15:00 h January 5, 1998. The horizontal transect was constructed in the main chamber with temperature sensors placed approximately every $4 \mathrm{~m}$ from the entrance to the rear. The vertical transect was constructed with a rope suspended at the rear of the cave from the ceiling to the bottom of a pit containing standing water. The temperature sensors were attached to the rope every $0.4 \mathrm{~m}$.

The third cave, Cueva de los Pajaros, is located on Isla de Mona, Puerto Rico (Fig. 4). Isla de Mona is a kidney-shaped, tectonically uplifted carbonate island approximately halfway between Puerto Rico and Hispaniola. The island is approximately $12 \mathrm{~km}$ long and $5 \mathrm{~km}$ wide with a total area of $55 \mathrm{~km}^{2}$. Puerto Ricans refers to the island as a meseta, describing the flat-topped, raised platform bounded on all sides by vertical cliffs. The vertical cliffs range from 20 to $80 \mathrm{~m}$ in height. The caves of Isla de Mona are flank margin in origin and are located on the periphery of the island, ranging in size from several square meters to a series of large interconnected rooms that extend more than $1 \mathrm{~km}$ with $150000 \mathrm{~m}^{2}$ floor area. Cave development is 


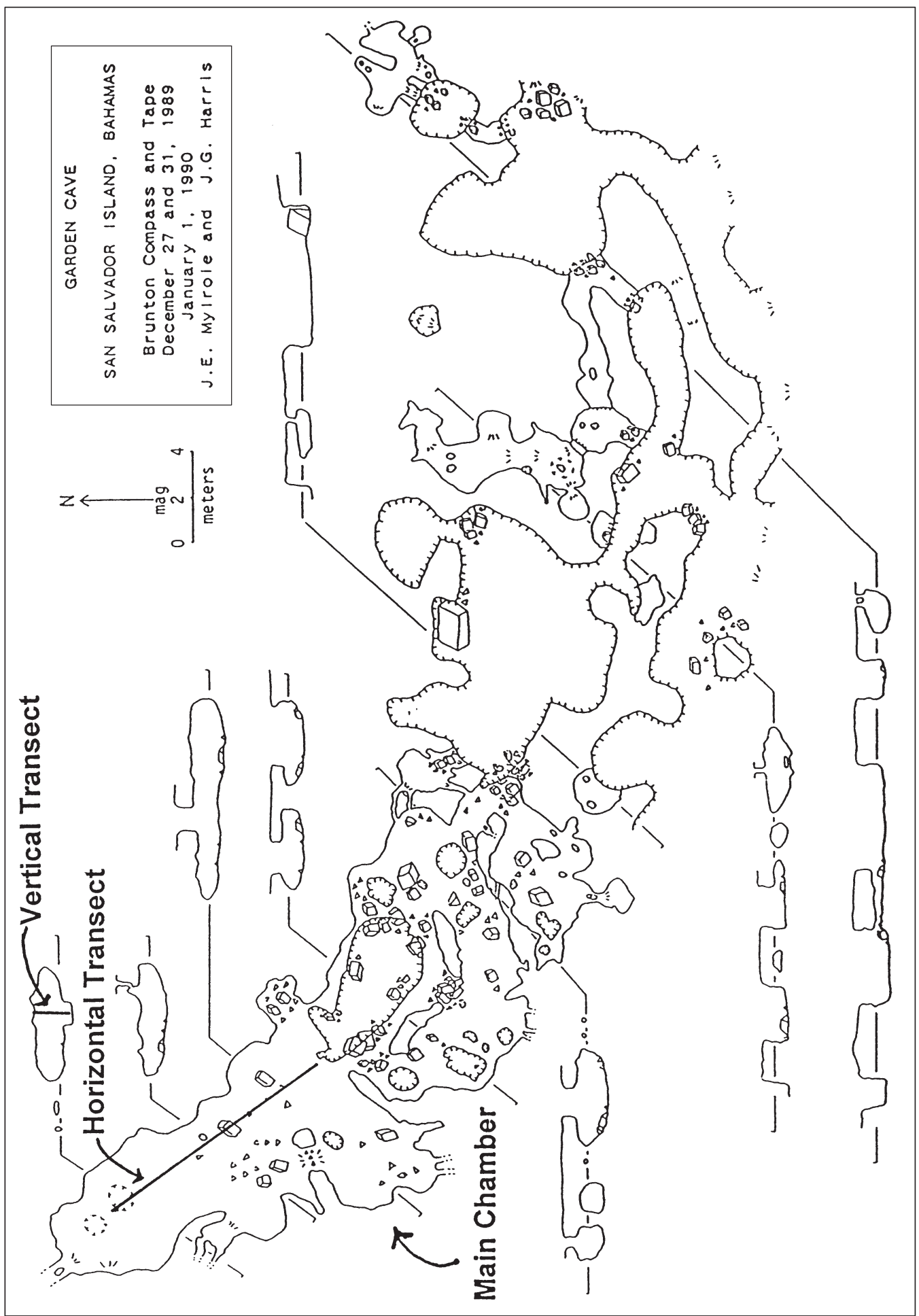

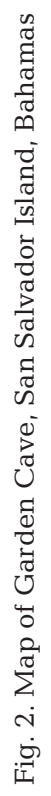


typically restricted to a zone extending $240 \mathrm{~m}$ inland from cliff faces (Frank et al. 1998).

Cueva de los Pajaros has the second largest floor area of any cave on Isla de Mona at $128000 \mathrm{~m}^{2}$. The main body of the cave is oriented southwest-northeast and occupies an area $500 \mathrm{~m}$ long and extends $200 \mathrm{~m}$ into the cliff side (Frank 1993). The entrances to the cave face southeast and are typically wide, and inward from the entrance are several large domed rooms up to 15-40 $\mathrm{m}$ across and $100 \mathrm{~m}$ long. The ceilings are arched and commonly more than $8 \mathrm{~m}$ high. Moving inland, the rooms become smaller. There is no consis-

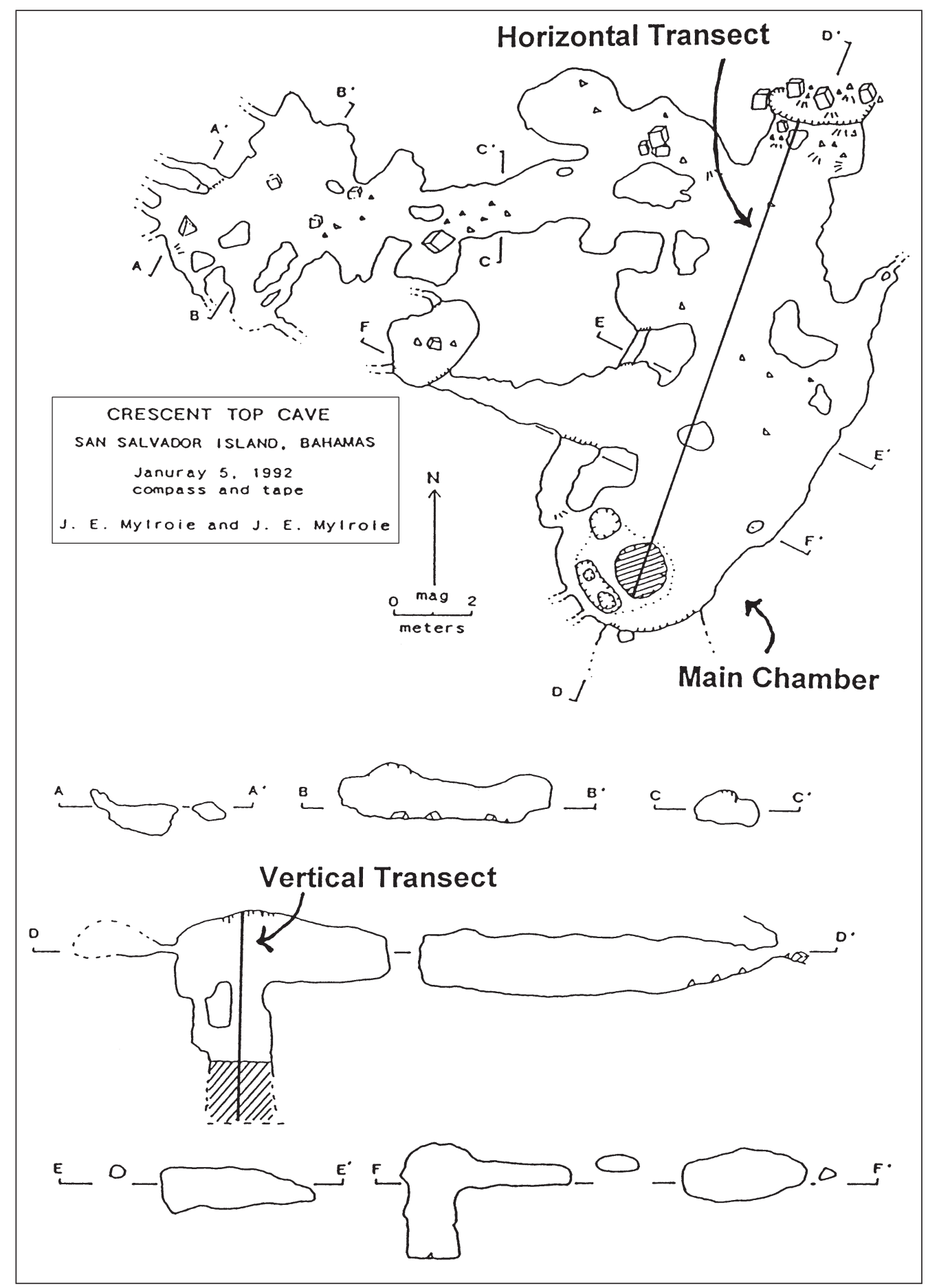

Fig. 3. Map of Crescent Top Cave, San Salvador Island, Bahamas 
tent slope to the cave floor, and locally the cave has levels, with levels being separated by horizontal septas of bedrock as much as 3 m thick (Briggs 1974).

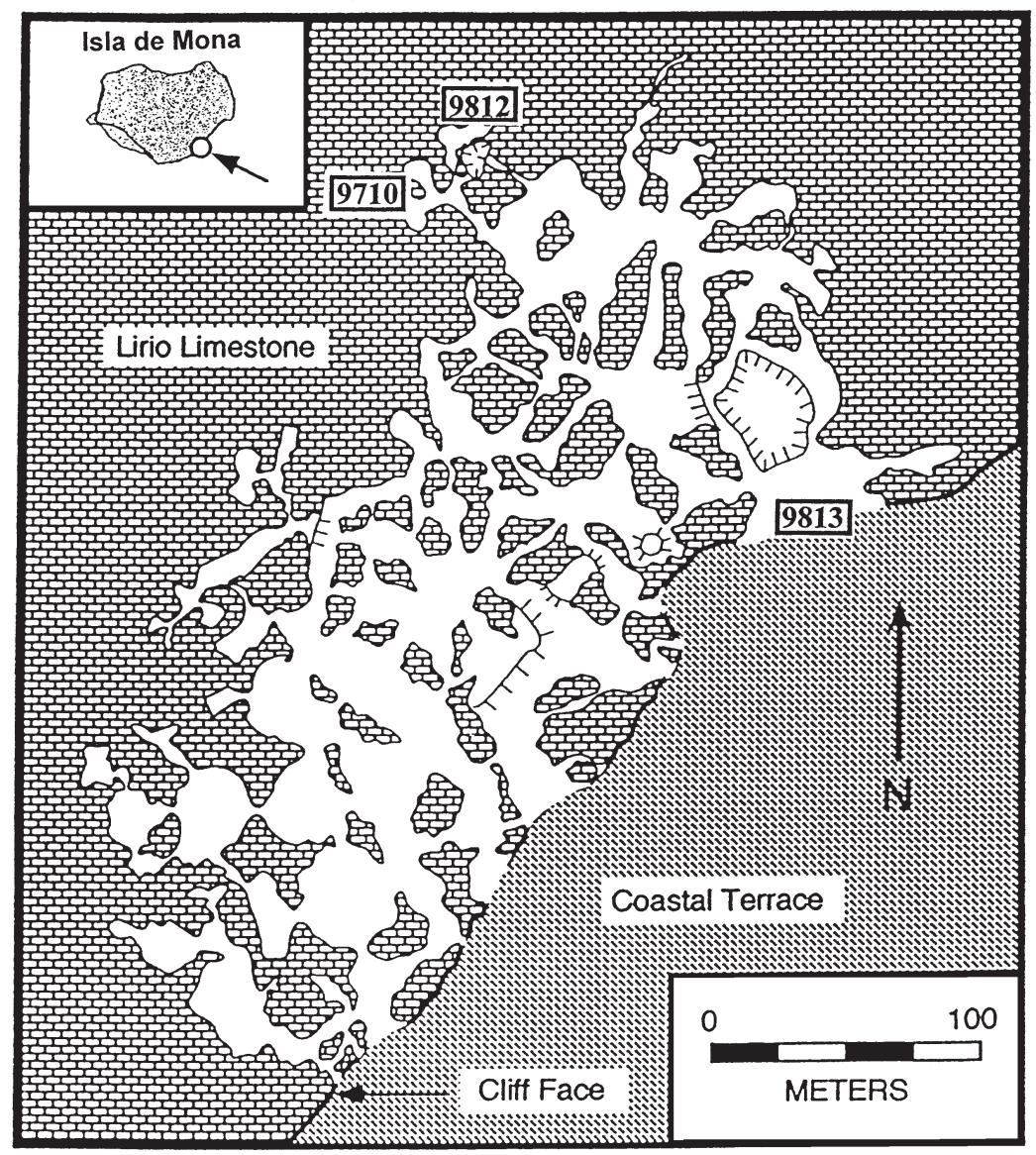

Fig. 4. Location and map of Cueva de los Pajaros, Isla de Mona, Puerto Rico. The numbers indicate the positions of the temperature sensors. Sensor 9813 was placed at the entrance of the cave, 9812 was placed on the floor at the entrance of the cave, and 9710 was placed on a ledge $3 \mathrm{~m}$ above the floor at the rear of the cave. (Modified from Gonzalez et al. 1997)
Temperature sensors in Cueva de los Pajaros collected temperature observations every $20 \mathrm{~min}$ from 15:30 h June 11 to 18:00 h June 20, 1998. Only 3 temperature sensors were available for data collection. One data logger was placed in the entrance of the cave, 4 $\mathrm{m}$ above the cave floor (Fig. 4). The remaining 2 temperature sensors were placed at the rear of the cave, one at floor level and one on a ledge $3 \mathrm{~m}$ above the cave floor.

\section{RESULTS}

\subsection{Garden Cave, San Salvador Island, Bahamas}

Observations from the horizontal transect indicate cooler conditions near the entrance, mean temperature $22.0^{\circ} \mathrm{C}$, and warm conditions at the rear, mean temperature $23.8^{\circ} \mathrm{C}$ (Table 1). The vertical transect observations indicate cool conditions at the floor of the cave, mean temperature $22.5^{\circ} \mathrm{C}$, and warmer conditions at the ceiling of the cave, mean temperature $24.1^{\circ} \mathrm{C}$ (Table 1). Statistical analysis indicates that variance in temperatures decreases from the entrance, coefficient of variation 0.742 , to the rear of the cave, coefficient of variation 0.324 , and from the floor, coefficient of variation 0.056 , to the ceiling of the cave, coefficient of variation 0.009 (Table 1). Linear regression models indicate that exterior temperatures explain less vari-

Table 1. Descriptive statistics and linear regression results for Garden Cave

\begin{tabular}{|c|c|c|c|}
\hline Data logger & $\begin{array}{c}\text { Mean temperature } \\
\left({ }^{\circ} \mathrm{C}\right)\end{array}$ & Coefficient of variance & $\begin{array}{l}\text { Linear regression with } \\
\text { exterior temperature }\left(\mathrm{r}^{2}\right)\end{array}$ \\
\hline \multicolumn{4}{|c|}{ (A) Horizontal transect } \\
\hline 9706 (Back) & 23.8 & 0.0324 & 0.74 \\
\hline 9707 & 22.7 & 0.0507 & 0.74 \\
\hline 9708 & 22.3 & 0.0669 & 0.80 \\
\hline 9709 (Front) & 22.0 & 0.0742 & 0.90 \\
\hline 9710 (Exterior) & 21.5 & 0.1340 & \\
\hline \multicolumn{4}{|c|}{ (B) Vertical transect } \\
\hline 9701 (Ceiling) & 24.1 & 0.0091 & 0.39 \\
\hline 9702 & 23.4 & 0.0290 & 0.73 \\
\hline 9703 & 22.8 & 0.0491 & 0.75 \\
\hline 9704 (Floor) & 22.5 & 0.0560 & 0.72 \\
\hline
\end{tabular}




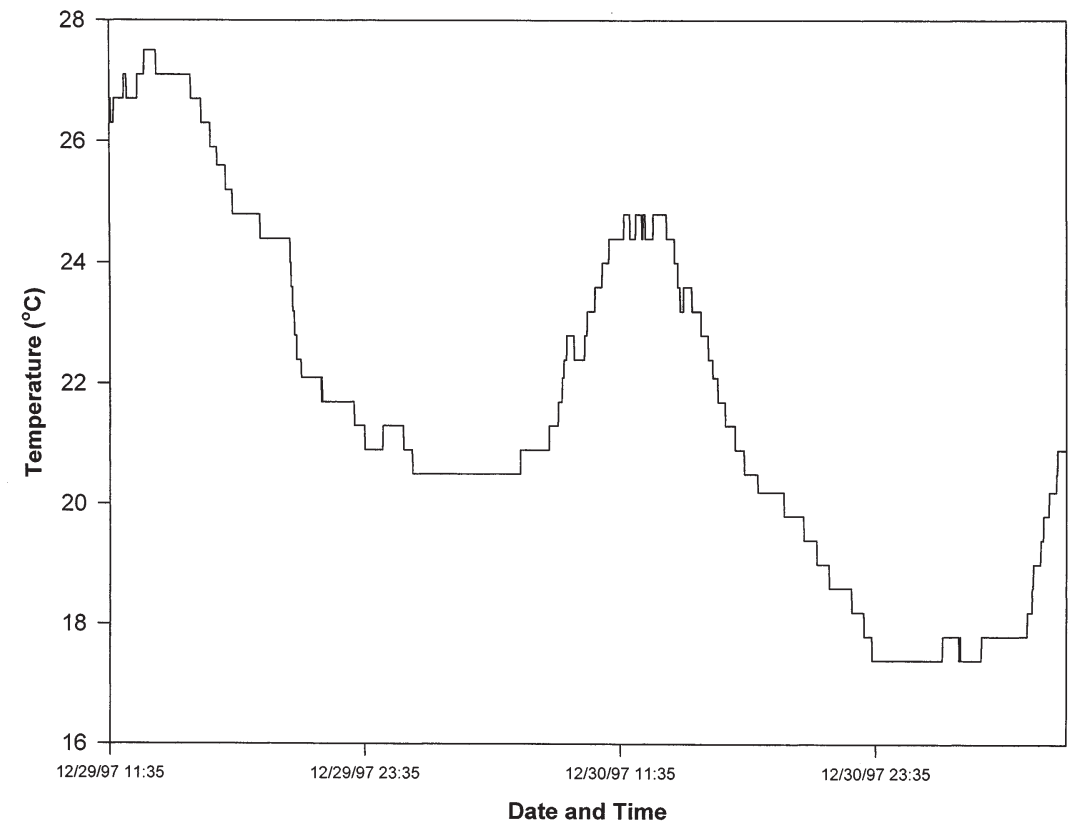

Fig. 5. Seven-term (10.5 min) moving average of temperature observations from outside Garden Cave moving from the entrance, coefficient of variation 0.012 , to the back, coefficient of variation 0.009 (Table 2). Since the data collection period for Crescent Top Cave followed the passage of the trough that affected San Salvador Island on December 31, 1997, a general warming temperature can be observed in the exterior temperatures and temperatures from the horizontal transect (Figs. 8 \& 9). This warming trend represents the modification of the cool, dry continental air mass which moved over the island after passage of the trough. It should be noted that 2 intense thunderstorms affected the northern part of San Salvador during the Crescent Top Cave data collection period (January 3 and 5, 1998). These storms caused a quick drop in exterior air temperatures. However, these short-term temperature variations were not evident in the temperature data collected simultaneously within Crescent Top Cave (Fig. 9).

Temperature observations from the vertical transect in Crescent Top Cave represent a very different vertical thermal environment as compared to Garden Cave. Temperatures are warmer on the floor of the cave, mean temperature $27.5^{\circ} \mathrm{C}$, and decrease moving up ance in cave temperatures moving from the entrance to the rear, $\mathrm{r}^{2}=0.90$ to 0.74 , and from the floor to the ceiling of the cave, $\mathrm{r}^{2}=0.72$ to 0.39 (Table 1 ).

Despite the decrease in the effect of exterior conditions deep in the cave, all portions of the cave displayed influence from a storm as it passed across the island on the night of December 31, 1997. The passage of an atmospheric trough brought behind it a cool, dry air mass from the continental United States, causing a drop in temperatures across the Bahamas. This decrease in temperatures can be seen in the observations recorded by each data logger (Figs. 5, 6 \& 7). The largest decrease in temperature was at the cave entrance and floor, while the smallest decrease in temperatures was at the rear and ceiling of the cave.

\subsection{Crescent Top Cave}

Temperature observations from the horizontal transect indicate Crescent Top Cave was cool near the entrance, mean temperature $25.0^{\circ} \mathrm{C}$, and warm at the rear of the cave, mean temperature $25.6^{\circ} \mathrm{C}$ (Table 2). In addition, the variance of temperatures decreases

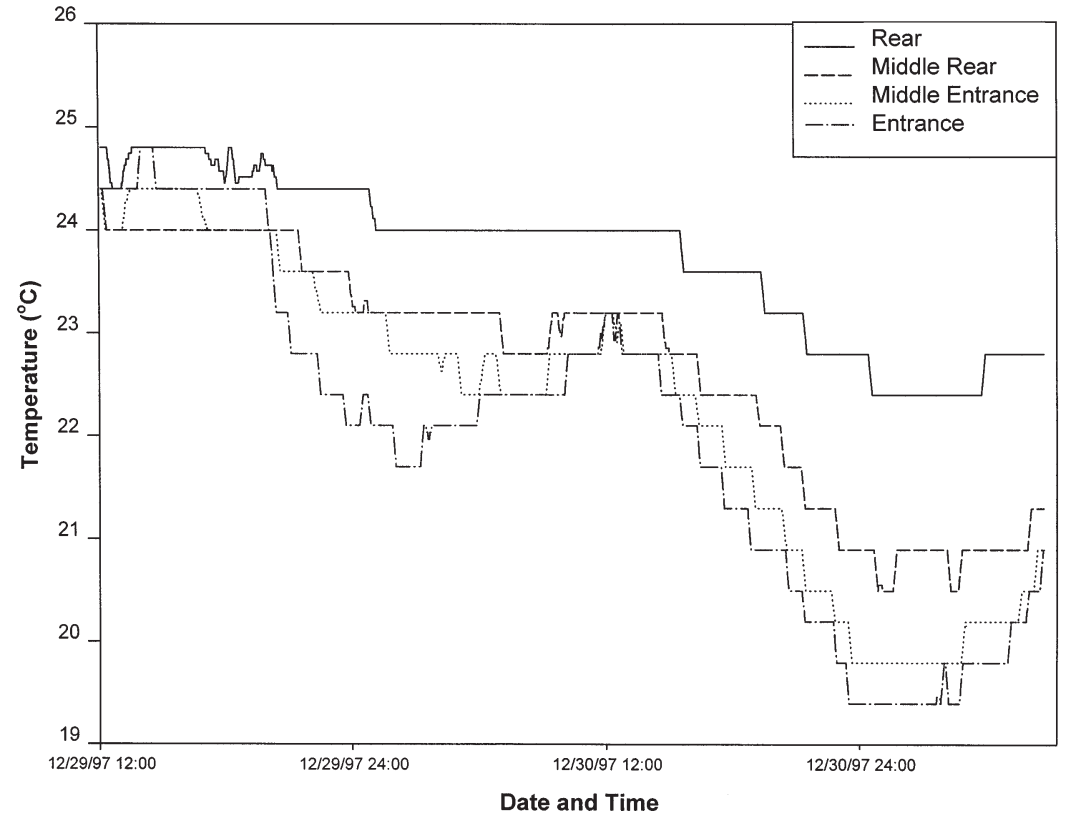

Fig. 6. Seven-term (10.5 min) moving average of temperature observations from Garden Cave horizontal transect 


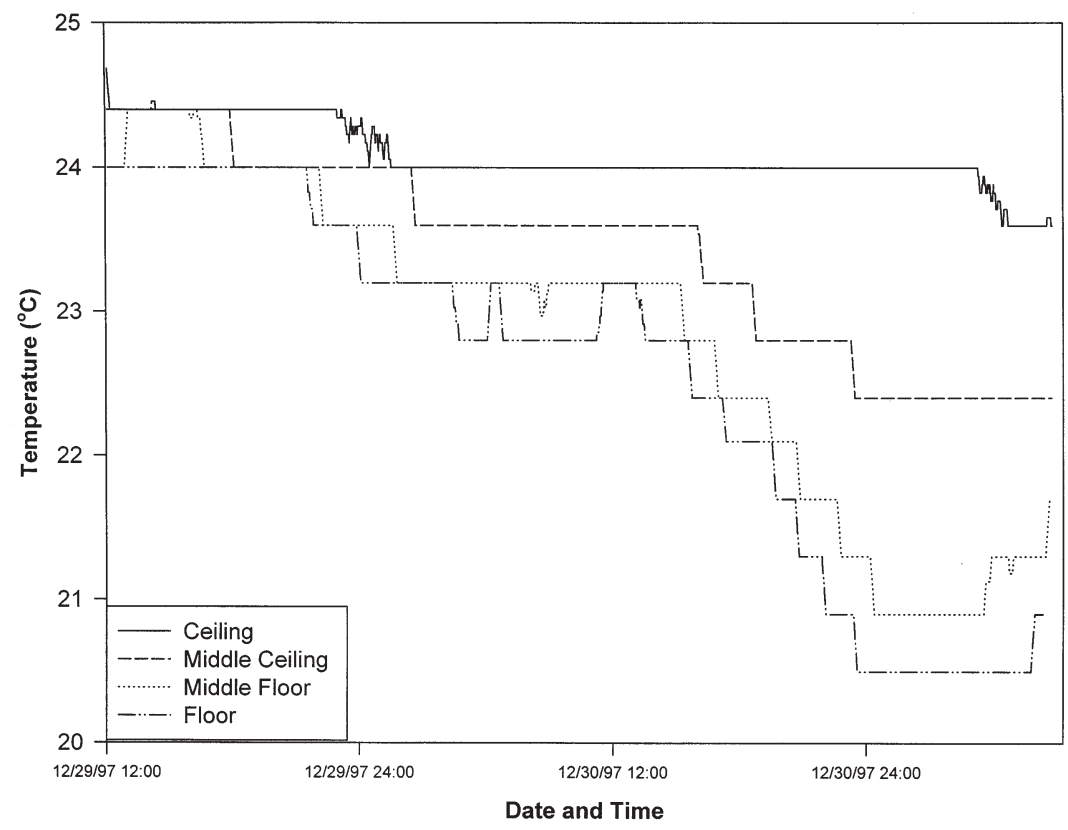

Fig. 7. Seven-term (10.5 min) moving average of temperature observations from Garden Cave vertical transect

Crescent Top Cave raising the temperature of the tidal pool and the air column directly above it through conduction. Once this warmer water is inside the cave, heat is absorbed by the rock surrounding water causing the water and air temperature to decrease. This process repeats itself again as the next high tide enters the cave system.

\subsection{Cueva de los Pajaros}

The data logger at the entrance of the cave displayed a distinct diurnal pattern (Fig. 12). The morning temperatures rise very quickly to a daily peak temperature between 32 and $36^{\circ} \mathrm{C}$, then temperature steadily declines for the remainder of the day. The maximum daily temperature in the morning seems peculiar due to the fact that daily maximum temperatures usually occur in the late afternoon,

towards the ceiling, mean temperature $26.1^{\circ} \mathrm{C}$ (Table 3). In addition to this temperature gradient the vertical profile can be separated into 2 components, tidal and nontidal. In the nontidal component, the air temperatures display a warming trend after passage of the trough and no variability at the ceiling of the cave (Fig. 10). The tidal component displays warmer conditions near the bottom of the tidal pool, and cooler conditions above the pool. In addition to this temperature gradient, there was a cyclical pattern in the temperatures (Fig. 11). The cyclical pattern shows a rise and fall in temperatures twice a day. This rise and fall in temperatures corresponds with the tidal chart from Nassau, Bahamas. The rise in temperatures corresponds with high tide and the decrease in temperatures corresponds with low tide. This observation is interpreted as resulting from the tidal water sits in Crescent Pond, near Crescent Top Cave, absorbing incoming solar radiation, increasing water temperature. As the tide begins to rise, this water flows into once longwave radiation is emitted from the Earth back into the atmosphere (Barry \& Chorley 1992). In addition, given the mean maximum daily temperature for Mona Island in June is $32.2^{\circ} \mathrm{C}$ (NCDC 1995), the maximum temperatures 32 to $36^{\circ} \mathrm{C}$ at the cave entrance seem suspect.

This diurnal pattern with a maximum temperature in the morning may be explained by the orientation of the cave entrance, which faces the southeast. As the sun rises the solar angle is low and sunlight can travel unimpeded into the cave entrance. The sun's rays can then directly strike the data logger case, causing thermal loading and an exaggerated temperature. However, once the solar angle increases, sunlight does not reach into the cave entrance and the data logger is in the shade, causing temperature to drop quickly. Thus, it may be more appropriate to assume the maximum temperature within the cave is more accurately estimated by late morning observations, which were approximately 30 to $32^{\circ} \mathrm{C}$. The temperature sensors in

Table 2. Descriptive statistics and linear regression results for horizontal transect in Crescent Top Cave

\begin{tabular}{|c|c|c|c|}
\hline Data logger & $\begin{array}{l}\text { Mean temperature } \\
\left({ }^{\circ} \mathrm{C}\right)\end{array}$ & Coefficient of variance & $\begin{array}{l}\text { Linear regression with } \\
\text { exterior temperature }\left(\mathrm{r}^{2}\right)\end{array}$ \\
\hline H12 (Back) & 25.6 & 0.0086 & 0.25 \\
\hline H13 & 25.2 & 0.0103 & 0.32 \\
\hline H14 (Front) & 25.0 & 0.0116 & 0.27 \\
\hline H15 (Exterior) & 22.9 & 0.0488 & \\
\hline
\end{tabular}




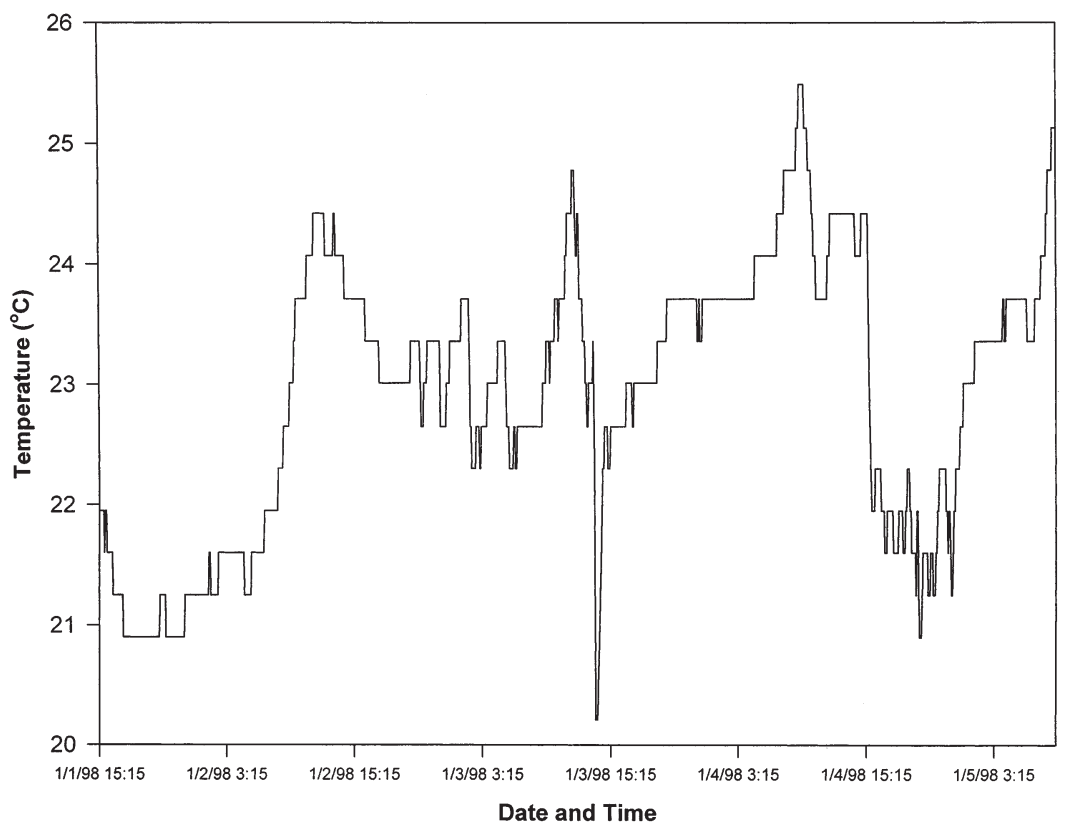

Fig. 8. Seven-term (35 min) moving average of temperature observations outside Crescent Top Cave

the rear of Cueva de los Pajaros show no variance and are consistent throughout the period of observation, mean temperatures of 26.7 and $26.3^{\circ} \mathrm{C}$.

\subsection{Three cave comparison}

A comparison of the results for the 3 caves indicates that Cueva de los Pajaros has the warmest mean temperature (Table 4). However, this includes the exaggerated morning temperatures that may be created by thermal loading in the data logger case. If a more accurate daily maximum value of $31^{\circ} \mathrm{C}$ is assumed for Cueva de los Pajaros, the new mean temperature is $27.3^{\circ} \mathrm{C}$, still making it the warmest of the 3 caves. The reason for this high mean temperature may be linked to the sampling period. The observations for Cueva de los Pajaros were collected in June, while observations in the Bahamas were collected in the winter. The mean maximum temperature for Isla de Mona in June is $32.2^{\circ} \mathrm{C}$ and for San Salvador in December $27.0^{\circ} \mathrm{C}$. Due to the large opening of Cueva de los Pajaros this warm air can easily travel into the cave system and raise the ambient temperature. It should be noted that the mean temperature of Crescent Top Cave is close to that of Cueva de los Pajaros. The reason for this high mean temperature in Crescent Top Cave is a small opening which limits the circulation of cooler winter air and the heat source created by tidal water at the rear of the cave increases ambient temperatures.

In terms of variance, Cueva de los Pajaros displays the greatest variance in cave temperature observations, coefficient of variation 0.062, followed by Garden Cave, coefficient of variation 0.058, and Crescent Top Cave, coefficient of variation 0.029 (Table 4). However, after removing all temperatures greater than $31^{\circ} \mathrm{C}$, the coefficient of variation for Cueva de los Pajaros, 0.048, drops below that for Garden Cave. This is an unexpected result given the multiple, large entrances to Cueva de los Pajaros. However, given the absence of variance in the rear Cueva de los Pajaros, the measure of variance for the entire cave will be low. In Garden Cave, since all locations experience some variance in temperature, the variability for the entire cave will be greater.

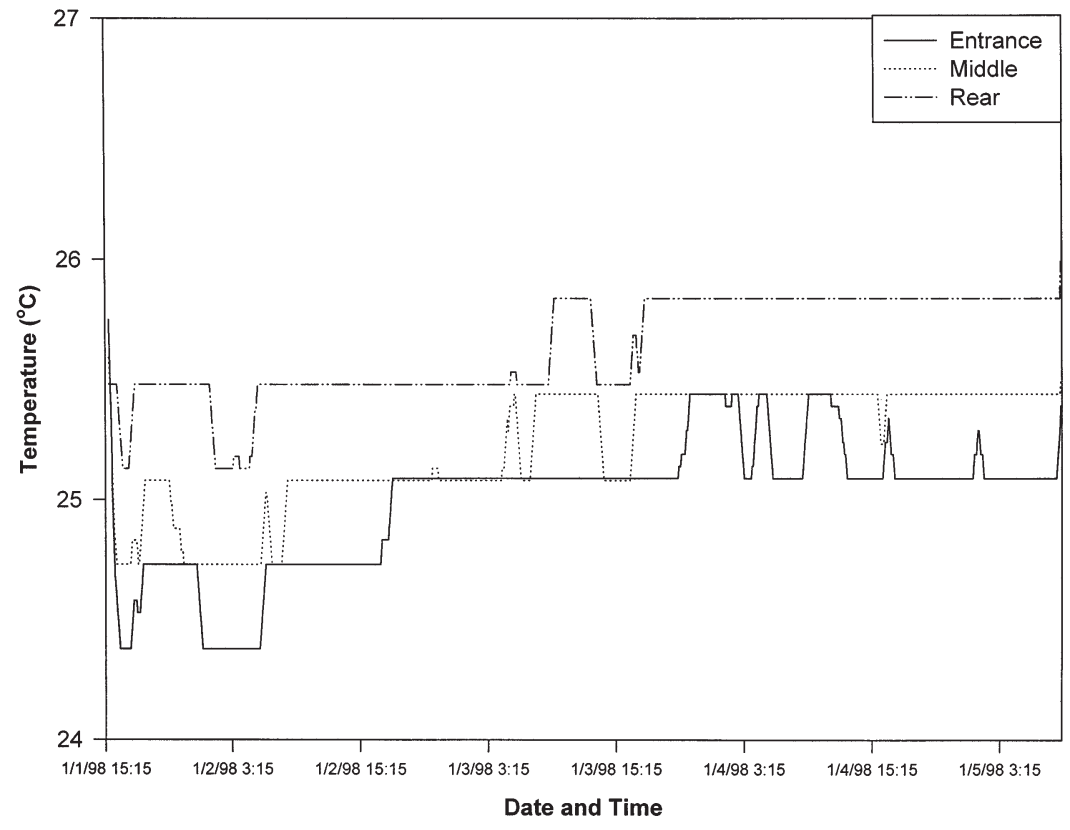

Fig. 9. Seven-term (35 min) moving average of temperature observations from Crescent Top Cave horizontal transect 
Table 3. Descriptive statistics and linear regression results for vertical transect in Crescent Top Cave

\begin{tabular}{|c|c|c|c|}
\hline Data logger & $\begin{array}{c}\text { Mean temperature } \\
\left({ }^{\circ} \mathrm{C}\right)\end{array}$ & Coefficient of variance & $\begin{array}{l}\text { Linear regression with } \\
\text { exterior temperature }\left(\mathrm{r}^{2}\right)\end{array}$ \\
\hline H11 (Ceiling) & 26.1 & 0.0015 & 0.0034 \\
\hline H10 & 26.1 & 0.001 & 0.0009 \\
\hline H9 & 26.0 & 0.0031 & 0.0800 \\
\hline H8 & 26.1 & 0.0023 & 0.0500 \\
\hline H7 (Cave floor) & 26.3 & 0.0034 & 0.1200 \\
\hline H6 & 26.7 & 0.0041 & 0.0520 \\
\hline H5 & 26.9 & 0.0119 & 0.0580 \\
\hline $\mathrm{H} 4$ & 27.0 & 0.0074 & 0.0002 \\
\hline H3 & 27.5 & 0.0058 & 0.0250 \\
\hline H1 (Pit bottom) & 27.5 & 0.0033 & 0.0340 \\
\hline
\end{tabular}

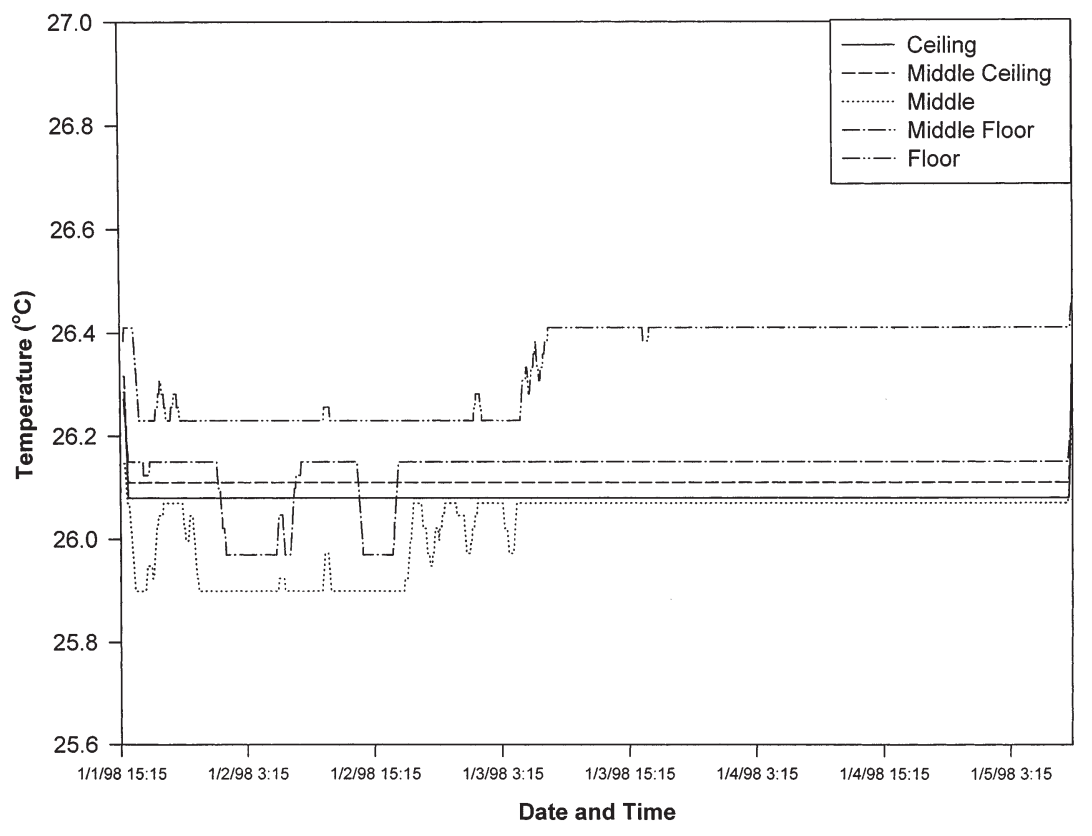

Fig. 10. Seven-term (35 min) moving average of temperature observations from Crescent Top Cave nontidal vertical transect

Cave. The influence of the external disturbances diminishes from the entrance to the rear. The interesting aspect of the impact of the external disturbance is that even though the entrance of Crescent Top Cave is small, it does not appear to significantly diminish the flow of air in the cave and variability in cave temperature.

The second characteristic is that during winter caves are warmer than the exterior temperatures. Such a seasonal difference in external air temperatures and cave air temperatures has been documented in previous studies (de Freitas \& Littlejohn 1987). The mean exterior temperatures for Garden Cave and Crescent Top Cave are 21.5 and $22.9^{\circ} \mathrm{C}$, cooler than the mean cave temperatures of 22.9 and $26.2^{\circ} \mathrm{C}$ respectively. Exterior and cave temperature could not be compared for Cueva de los Pajarros on Isla de Mona due to insufficient data loggers. Thus, data is not available to assess

\section{DISCUSSION}

Temperature observations were collected inside caves of the Bahamas and Puerto Rico in order to characterize the microclimatology of tropical cave systems. Three general characteristics of tropical cave systems can be drawn from these observations that concur with existing temperate cave microclimate theory. The first characteristic is that external atmospheric disturbances can affect temperatures of tropical flank margin cave systems. On San Salvador Island, the passage of an atmospheric trough caused a decrease in the temperature of Garden Cave, and after the passage of the trough temperatures increased in Crescent Top the potential summer exterior-cave temperature relationship.

The third characteristic of the tropical flank margin caves which agrees with temperate cave microclimate theory is that water can impact temperatures deep into a cave system. It has been recognized that lakes and rivers in temperate caves are capable of modifying the cave atmosphere, causing variability in cave microclimatology (Wigley \& Brown 1976, Moore \& Sullivan 1978, Dublyansky \& Dublyansky 1998). However, the influence of water in Crescent Top Cave is different from the typical influence of a stream or lake in a temperate cave. The tidal pulse and unique hydrology of San Salvador Island create the cyclical pattern in the 


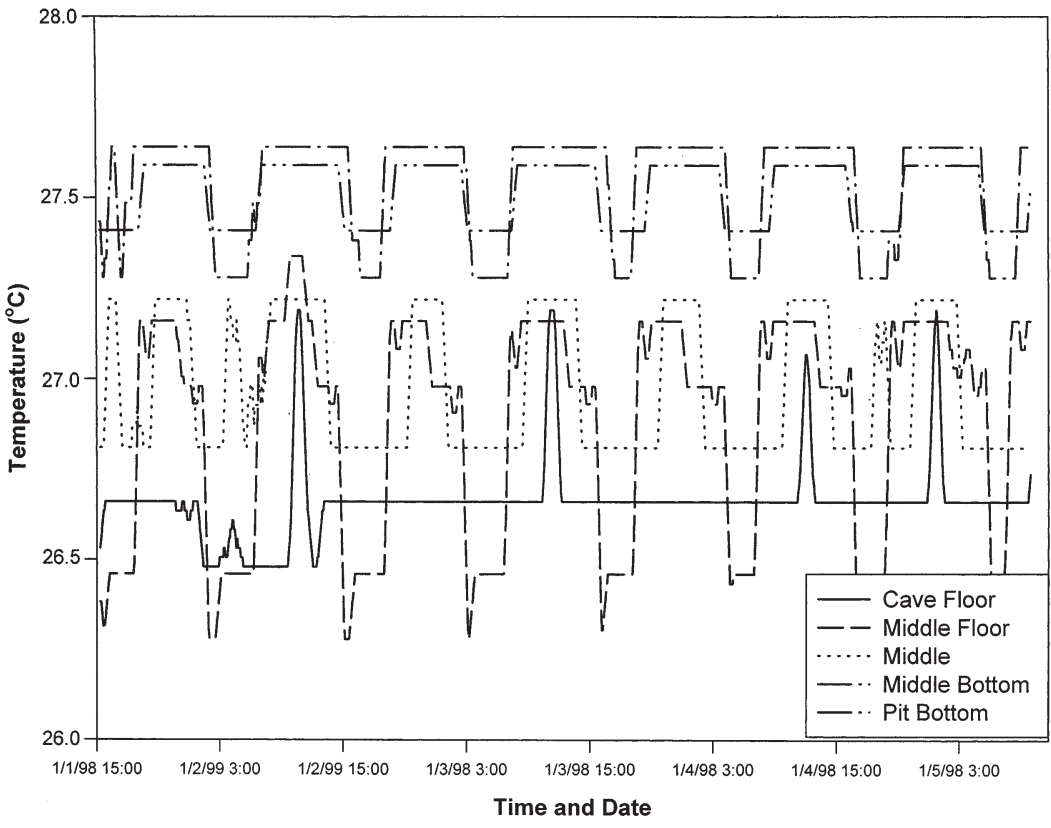

Fig. 11. Seven-term (35 min) moving average of temperature observations from Crescent Top Cave tidal vertical transect

cave water temperature and the cave air above the water. Such cyclical patterns are rare in temperate fluvial cave systems.

The temperature observations from the 3 caves also indicate potential differences in the microclimatology of tropical and temperate cave systems. A total of 3 potential differences can be identified from the temperature observations. The first difference is that the temperate 3-zone cave microclimate model may not be applicable to tropical flank margin caves. According to this model, 3 climate zones exist in a cave, a twilight zone, a middle zone, and a deep cave zone (Cropley 1965, Poulson \& White 1969, Niven \& Hood 1978). In the twilight zone near the cave entrance the greatest variability in climate parameters exists. In the middle zone, complete darkness exists with some variability in cave climate, and in the deep cave zone constant climatic conditions exist. The temperate 3-zone cave climate model is not appropriate for the Bahamian caves because a deep cave zone without variance does not exist. One reason for the absence of this zone is the rounded shallow chambers of the flank margin caves. Due to this shape, air can reach the rear of the cave, causing variabil- ity. In addition, the existence of tidal water (as in the case of Crescent Top Cave) can cause variability in temperatures at the rear of a cave.

A second potential difference between tropical and temperate cave systems is that diurnal fluctuations were not apparent in all tropical cave systems. Previous studies have noted that in climate zones with temperature variability in temperate caves, there is a small but unmistakable diurnal fluctuation in temperature corresponding with external temperature cycles (Forbes 1998). Although diurnal fluctuations were found in Puerto Rico, they were not found in the Bahamas. The Bahamian caves have much smaller opening than the Puerto Rican cave, inhibiting free exchange of air and resulting diurnal fluctuations. Thus, a more accurate statement regarding diurnal fluctuations in tropical caves is the following: in multi-entrance dynamic caves diurnal fluctuations can exist in cave temperatures, but in single-entrance static caves the diurnal fluctuation in cave temperature is unlikely.

The final difference between the microclimate of tropical and temperate cave systems is that a temperature inversion does not necessarily exist in down-

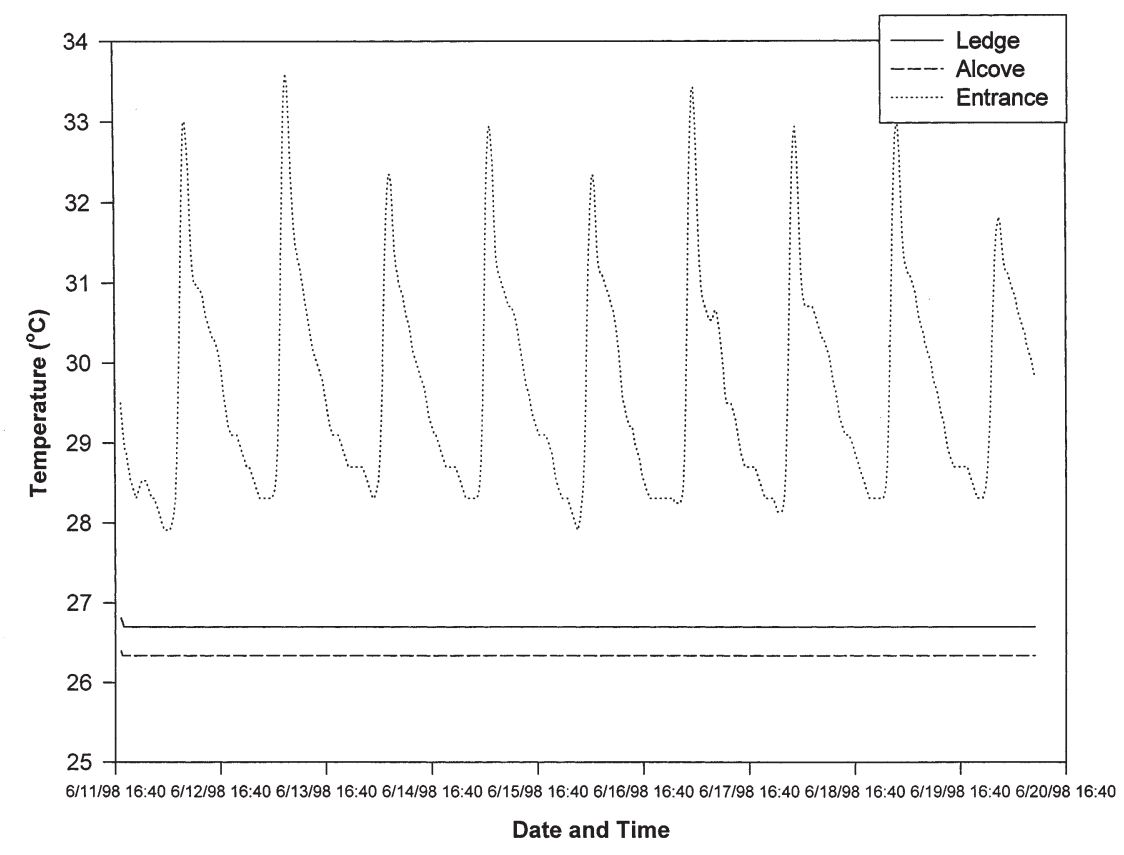

Fig. 12. Seven-term (140 min) moving average of temperature observations from Cueva de los Pajaros, Isla de Mona, Puerto Rico 
Table 4. Descriptive statistics for Bahamian and Puerto Rican caves

\begin{tabular}{|c|c|c|c|c|c|c|c|c|}
\hline Cave & $\begin{array}{c}\text { Mean } \\
\left({ }^{\circ} \mathrm{C}\right)\end{array}$ & $\begin{array}{l}\text { Standard } \\
\text { deviation }\end{array}$ & Range & $\begin{array}{l}\text { Coefficient } \\
\text { of variance }\end{array}$ & $\begin{array}{c}\text { Exterior } \\
\text { mean } \\
\left({ }^{\circ} \mathrm{C}\right)\end{array}$ & $\begin{array}{c}\text { Exterior } \\
\text { standard } \\
\text { deviation }\end{array}$ & $\begin{array}{c}\text { Exterior } \\
\text { range } \\
\left({ }^{\circ} \mathrm{C}\right)\end{array}$ & $\begin{array}{c}\text { Exterior } \\
\text { coefficient } \\
\text { of variance }\end{array}$ \\
\hline Garden Cave & 22.9 & 1.33 & $19.4-24.8$ & 0.058 & 21.5 & 2.89 & $17.4-27.5$ & 0.134 \\
\hline Horizontal & 22.7 & 1.47 & $19.4-24.8$ & 0.065 & & & & \\
\hline Vertical & 23.2 & 1.10 & $20.5-24.8$ & & & & & \\
\hline Crescent Top Cave & 26.3 & 0.77 & $24.4-27.6$ & 0.029 & 22.9 & 1.12 & $20.2-25.5$ & 0.049 \\
\hline Horizontal & 25.3 & 0.37 & $24.4-26.5$ & 0.015 & & & & \\
\hline Vertical & 26.6 & 0.57 & $25.9-27.6$ & 0.021 & & & & \\
\hline Tidal & 27.0 & 0.47 & $26.2-27.6$ & 0.017 & & & & \\
\hline Nontidal & 26.1 & 0.06 & $25.9-26.5$ & 0.002 & & & & \\
\hline Cueva de los Pajaros & 27.8 & 1.72 & $26.3-36.6$ & 0.062 & & & & \\
\hline With $31^{\circ} \mathrm{C}$ max. & 27.3 & 1.29 & $26.3-30.7$ & 0.048 & & & & \\
\hline Front & 26.7 & & & & & & & \\
\hline Back & 26.3 & & & & & & & \\
\hline
\end{tabular}

sloping tropical flank margin caves. Previous research has indicated the vertical temperature gradients in a cave are most strongly controlled by the physical structure of the cave system. In particular, with a cave entrance above the cave floor, the densest (coolest) air flows toward the lowest points of the cave, creating a permanent inversion (Wigley \& Brown 1976). The floor of Crescent Top Cave is below the entrance of the cave. However, in the rear of the cave above the tidal pit a temperature inversion does not exist; the warmest air is at the floor and the coolest is at the ceiling of the cave. The authors believe that Crescent Top Cave did not have a temperature inversion due to the heat source created by the tidal pool at the rear of the cave. The existence of a tidal pool is rare in the temperate fluvio-karst caves and is therefore not accounted for in the prevailing literature.

In conclusion, the potential differences in temperate and tropical cave systems can be linked to the physical dimensions of the tropical flank margin cave systems and the unique hydrology of small carbonate islands. Temperate fluvio-karst caves are characterized by much narrower and more vertically extensive passage networks as compared to the wide, globular, shallow tropical flank margin caves. The globular, shallow flank margin caves create an environment where a true deep cave microclimate zone cannot develop, and the entire cave is subject to influence from the external atmosphere. However, this influence may not include diurnal fluctuation, which is restricted by the small entrances to flank margin caves. The probable cause of climate variability in tropical flank margin caves can be attributed to passing external atmospheric disturbances or the existence of tidal water. The hydrology of small carbonate islands can be very complicated, with the existence of a fresh/saltwater mixing zone and influences of ocean tides and currents that create a dif- ferent cave microclimate as compared to fluvio-karst caves, which are dominated by flowing streams. Such microclimates can have cyclical variation due to inflow and outflow of tidal water into a cave system.

Acknowledgements. The authors wish to thank Dr Horton Hobbs III, Department of Biology, Wittenburg University, for lending his temperature sensors. In addition, Annette Summers-Engel, Mike Goldstein, Megan Porter, and Lee Seal were invaluable as field assistants, and Dr Larry Davis' insight into the complex hydrology of San Salvador helped with interpretation of data. The Bahamian Department of Agriculture and Kenny Buchan of the Bahamian Field Station provided the research permit (Permit no. 98/74) and invaluable logistical support for field research on San Salvador Island.

\section{LITERATURE CITED}

Barry RG, Chorley RJ (1992) Atmosphere, weather, and climate. Routledge, London

Bogli A (1980) Karst hydrology and physical speleology. Springer-Verlag, Berlin

Briggs RP (1974) Economic geology of the Isla de Mona quadrangle, Puerto Rico. US Geological Survey, Open File Report 74-226, Denver, CO

Carew JL, Mylroie JE (1995) Quaternary tectonic stability of the Bahamian archipelago: evidence from fossil coral reefs and flank margin caves. Quat Sci Rev 14:145-153

Carew JL, Mylroie JE (1997) Geology of the Bahamas. In: Vacher HL, Quinn TM (eds) Geology and hydrogeology of carbonate islands. Dev Sedimentol 54:91-139

Cropley JB (1965) The influence of surface conditions on temperatures in large cave systems. Nat Speleol Soc Bull 27(1):1-10

de Freitas CR, Littlejohn RN (1987) Cave climate: assessment of heat and moisture exchange. J Climatol 7:553-569

de Freitas CR, Littlejohn RN, Clarkson TS, Kristament IS (1982) Cave climate: assessment of airflow and ventilation. J Climatol 2:383-397

Dublansky VN, Dublansky YV (1998) The problem of condensation-corrosion in karst studies. J Cave Karst Stud 60(1):3-17 
Forbes J (1998) Air temperature and relative humidity study: Torgac Cave, New Mexico. J Cave Karst Stud 60(1):27-32

Frank EF (1993) Aspects of karst development and speleogenesis Isla de Mona, Puerto Rico: an analogue for Pleistocene speleogenesis in the Bahamas. MS thesis, Mississippi State University, Mississippi State

Frank EF, Mylroie JE, Troester J, Alexander EC, Carew JL (1998) Karst development and speleogenesis, Isla de Mona, Puerto Rico. J Cave Karst Stud 60(2):73-83

Gonzalez LA, Ruiz HM, Taggart BE, Budd AF, Monell V (1997) Geology of Isla de Mona, Puerto Rico. In: Vacher VL, Quinn T (eds) Geology and hydrogeology of carbonate islands. Dev Sedimentol 54:327-358

Moore GW, and Sullivan GN (1978) Speleology: the study of caves. Zephyrus Press, Inc, Teaneck, NJ

Mylroie JE, Carew JL (1990) The flank margin model for dissolution cave development in carbonate platforms. Earth Surf Process Landforms 15:413-424

Mylroie JE, Carew JL, Vacher HL (1995) Karst development in the Bahamas and Bermuda. In: Curran HA, White B (eds) Terrestrial and shallow marine geology of the Bahamas and Bermuda, Geological Society of America Special Paper 300. GSA, Denver, CO, p 251-267

National Climate Data Center (NCDC) (1995) NCDC summary of the day, East. CD-ROM, Earth Info Inc, Boulder, $\mathrm{CO}$

Editorial responsibility: Brent Yarnal, University Park, Pennsylvania, USA
Niven FM, Hood GM (1978) Diurnal atmospheric characteristics of the Sterkfontein tourist cave. S Afr J Sci 74:134-136

Panuska BC, Mylroie JM, Armentrout D, McFarlane D (1998) Magnetostratigraphy of Cueva del Aleman, Isla de Mona, Puerto Rico and the species duration of Audubon's Shearwater. J Cave Karst Sci 60(2):96-100

Poulson TL, White WB (1969) The cave environment. Science 165: 971-981

Ritter DF, Kochel RG, Miller JR (1995) Process geomorphology. WCB McGraw-Hill, Boston, MA

Shaklee R (1994) In Columbus's footsteps: geography of San Salvador Island, the Bahamas. Bahamian Field Station, San Salvador

Smithson PA (1993) Vertical temperature structure in a cave environment. Geoarchaeol Int J 8(3):229-240

Tarhule-Lips RFA, Ford DC (1998) Condensation-corrosion in caves on Cayman Brac and Isla de Mona. J Cave Karst Stud 60(2):84-95

Trapasso LM, Kaletsky K (1994) Food preparation activities and the microclimate within Mammoth Cave, KY. Nat Speleol Soc Bull 56:64-69

Wefer FL (1991) An annotated bibliography of cave meteorology. Cave Geol 2(2):84-119

Wigley TML, Brown MC (1976) The physics of caves. In: Ford TD, Cullingford CHP (eds) The science of speleology. Academic Press, London, p 329-350

Submitted: July 9, 1999; Accepted: May 5, 2000

Proofs received from author(s): September 19, 2000 